Farras Kartika Kusumadewi, Moses Glorino Rumambo Pandin

Faculty of Humanities, Airlangga University

Campus B, Jl. Dharmawangsa Dalam, Airlangga, Gubeng, Surabaya, Jawa Timur 60286

farras.kartika.kusumadewi-2020@fib.unair.ac.id, moses.glorino@fib.unair.ac.id

\title{
Book Review: \\ Sejarah Peradaban Islam (History of Islamic Civilization)
}

Ahmadin; Jakarta; 978-623-218-589-0; $x+162$ pages

The study of Islamic history today may not have been regulated through literature, either in foreign languages or using Indonesian (translations or works of the nation's children). Many books have studied the history of Islam that we can get to fill our information, but no one book is so complete, one literature with another can complement each other to form knowledge of Islamic history. From the thought that no single work is perfect and on the contrary will complement each other, the author of this book aims to present the book Sejarah Peradaban Islam to be a reference and teaching material for the history of Islamic civilization course. The author hopes that this work will not only serve as a reference for students majoring in history at various universities, but has also become a public reading as an important contribution to reinventing Islamic civilization in the past, present, and future.

Previously, this book entitled Sejarah Islam was only published in a limited edition (30 copies) by Rayhan Intermedia six years ago for student reading. After undergoing revisions in several parts as well as adjusting the curriculum and lecture materials, a book with the title Sejarah Peradaban Islam was presented. This book is intended for everyone, from all walks of life. Although it focuses on Islam, it can be read by anyone who wants to gain additional knowledge about Islamic history.

The flow of study in the book does not follow the periodization of Islamic history as written by Harun Nasution, which is divided into the classical period (650-1250 AD), the middle period (1250-1800 AD), and the modern period (1800 AD). His presentation in the book is more based on the growth and development of Islamic civilization in various regions and the reign of a certain caliph or king, however, it does not ignore the characteristics of the times and the character of the period in which Islam grew and developed. In certain parts of the book, it also reviews the roots and implications of the social revolution, the glorious achievements of the rulers, and the peaks of the development of Islamic civilization in various parts of the world.

The book of Sejarah Peradaban Islam from Ahmadin needs to be reviewed to know what is in the book, considering some of the previous things. In addition, also to find out what weaknesses and strengths are contained in the book, it is possible to recommend the book as additional reading for others.

This book is very important for readers, especially for students majoring in history or who are interested in knowing things about Islam. The book discusses the history of Islamic civilization, from the beginning of Islam to the spread of Islam in various parts of the world, such as the spread of Islam to Andalusia (Spain), North Africa, and several other places. The book is perfect for readers who want to know the origins and development of Islam.

In the beginning of the book, it is explained how the Arab conditions before the existence of Islam, ranging from spatial structure, social structure to religion and belief. Many changes occurred after the existence of Islam under the leadership of the Prophet Muhammad. After the death of the Prophet Muhammad, the leadership was replaced by those closest to the Prophet. or so-called Khulafaur-Rashidin.

Rasulullah went through a preaching period in Mecca full of suffering and concern, but he was still patient and did not complain. Even though he was treated badly, he always treated his opponents with a very good attitude. The Prophet's behavior in Mecca is truly an example of his attitude while in Mecca, showing extraordinary leadership qualities. He continued his work patiently and steadfastly and accepted all the mistreatment of unbelievers gracefully and was not discouraged and angry. He preached in a good way, did not force people's will to convert to Islam. Unlike the current conditions, sometimes some people like to impose their will on others. This shows that we should respect other people, even though their paths are different from ours. In addition, we can imitate the excellent attitude of the Prophet and other leaders that preaching is not as easy as imagined, but they still do not give up and keep trying. 
In the book there is some evidence that the author puts in this paper. These evidences are genuine evidence that can be accounted for, such as the presence of footnotes in discussions in books. For example, in the discussion of Abu Bakr's leadership, there is a footnote explaining whom Abu Bakr is with reliable reference sources.

The evidence in the book, from references, footnotes, and quotes taken, is compelling and proves that this book is guaranteed credibility. For example, in the discussion of the text of the Medina Charter where it is certain that the contents of the charter cannot be different from other sources.

There is a lot of evidence in books, for example, on page 37, on the discussion of Abu Bakr's leadership, it is explains a little about whom Abu Bakr is through footnotes. These footnotes are derived from references to the book Sejarah Peradaban Islam, which is the work of Samsul Munir Amin. Likewise, the contents of the Medina Charter text are accompanied by footnotes, even the Medina Charter has 2 versions, complete and short.

The style, organization, and size in the book fit the purpose perfectly. The style and organization in the discussion of this book is very easy for readers to understand. Some sections of the discussion in the book have a character like a story. This makes the explanations in the book easy for readers to understand. Its lightweight but weight is suitable for readers who want to know about the history of Islamic civilization. In addition, the discussion of Islamic civilization in the book is based on the periods that make the discussion of this book coherent.

However, several facts have been overlooked, one of which is how Islam can enter other regions, especially Spain. Regarding the Umayyad dynasty, the discussion about how its territory entered into Spanish territory is critical because Spain was the site of the Umayyad dynasty after the fall of the Umayyad dynasty from Damascus by supporters of the Abbasid dynasty. Readers need to look for additional references for the discussion, but overall the discussion is good.

The book is very suitable to be used as reading material and reference for readers who want to know about the history of Islam. The advantages contained in the book, namely the discussions contained in this book are classified in a coherent manner, classified according to their eras (periods), starting from the beginning of Islam from the leadership of the Prophet Muhammad to subsequent dynasties, and also its distribution to several regions outside Arab. In addition, the discussion is also supported by a very detailed explanation and supported by several facts through appropriate references.

On the other hand, this book also has weaknesses, one of which is the lack of illustrations in the chapter of the Dunia Arab Sebelum Islam, if only in the discussion about the location of Arabia or even the division of the region, there are pictures (map) that can describe the Arab region in the discussion so that the reader knows clearly the illustration. Apart from this, the weaknesses in this book are words or terms that may be a little foreign to the reader.

Suggestions for authors from reviewers suggest adding to the discussion or information about several events that will affect Islamic civilization in the future. The discussion led by the author is more complete, chronologically and illustrated to make it clearer. In addition to these shortcomings, the author's work is excellent and enriches the insights and perspectives of the readers.

Farras Kartika Kusumadewi \& Moses Glorino Rumambo Pandin Universitas Airlangga

\section{REFERENCE}

1. Ahmadin. Sejarah Peradaban Islam. Jakarta: KENCANA; 2020. x, 162 hlm.

\section{AUTHOR:}

Dr. Ahmadin, S.Ag., S.Pd., M.Pd. is a permanent lecturer at the Department of History, Faculty of Social Sciences (S-1) and Postgraduate Program (S-2) Universitas Negeri Makassar (UNM). He was born on February 24, 1972 in the Selayar Islands, South Sulawesi. Some of the teaching material books he has written include: Metode Penelitian Sosial, Sejarah Agraria: Sebuah Pengantar, dan Sejarah Pergerakan Nasional. Apart from writing books, he also edits several textbooks and references. 